\title{
MEMBANGUN RELASI DIGITAL ANTARA ORANG TUA SISWA DENGAN SEKOLAH DALAM PENANGANAN TAWURAN PELAJAR DI YOGYAKARTA
}

\author{
Muhadjir Darwin¹, Henny Ekawati², dan Fadlan Habib² \\ ${ }^{1}$ Fakultas IImu Sosial dan IImu Politik, Universitas Gadjah Mada, Yogyakarta, ${ }^{2}$ Pusat Studi \\ Kependudukan dan Kebijakan, Universitas Gadjah Mada, Yogyakarta \\ Korespondensi: Muhadjir Darwin (e-mail: d_muhadjir@yahoo.com)
}

\begin{abstract}
Abstrak
Tawuran antarpelajar yang menjurus pada tindakan kriminalitas (klithih) sedang marak di Daerah Istimewa Yogyakarta (DIY). Kondisi ini tidak terlepas dari melemahnya peran keluarga dan sekolah dalam pola pengasuhan anak. Tindakan negatif dalam bentuk aksi klithih merupakan perwujudan dari pencarian jati diri yang tidak tepat karena tindakan tersebut semata-mata mengedepankan kontrol diri yang lemah. Hasil penelitian menunjukkan bahwa 65,6 persen masyarakat Yogyakarta menyatakan kekerasan kelompok, terutama aksi klithih, meningkat dalam kurun waktu satu tahun terakhir. Penyebab utamanya adalah lemahnya peran orang tua dalam pengasuhan (65,7 persen), salah pergaulan (52,5 persen), dan lemahnya peran sekolah (36,2 persen). Upaya yang harus dilakukan dalam penanganan masalah tawuran pelajar adalah adanya sinergi yang baik antara pihak sekolah dan orang tua, di antaranya dengan meningkatkan komunikasi yang baik antara keduanya dalam pembinaan dan pengawasan pelajar, terutama model komunikasi personal dengan sentuhan teknologi informasi.
\end{abstract}

Kata kunci: tawuran pelajar, pola asuh, pendidikan karakter

\section{EFFORTS TO BUILD DIGITAL RELATIONS BETWEEN PARENTS AND SCHOOLS IN HANDLING STUDENTS BRAWLS IN YOGYAKARTA}

\begin{abstract}
Student brawls that lead to criminal activities called klithih (a Javanese term for violence among teenage students) is currently rampant in Yogyakarta Special Region (DIY). This condition is related to the weakening role of families and schools in nurturing the students. The negative action, klithih, is a manifestation of improper identity searching because it demonstrates a lack of self-control. The research showed that $65.6 \%$ of the community of Yogyakarta were agreed that group violence especially klithih had increased in the last year, and the main cause was the weakening role of parents $(65.7 \%)$, wrong association $(52.5 \%)$ and schools $(36.2 \%)$. Therefore, efforts must be made to create a good synergy between the schools and parents in handling student brawls. One of the efforts is improving good communication between the two parties in coaching and supervising teenage students, especially through a model of personal communication involving information technology.
\end{abstract}

Keywords: student brawl, parenting style, character education 


\section{Pendahuluan}

Fenomena kenakalan remaja yang menjurus pada tindakan kriminalitas yang dilakukan oleh para pelajar di Yogyakarta telah mencapai tahap memperihatinkan. Kenakalan remaja yang dimaksud dalam tulisan ini adalah tindakan tawuran atau klithih. Berdasarkan data dari Polda DIY, tahun 2016 terjadi 43 kasus tawuran pelajar yang para pelakunya berusia antara 14 sampai 18 tahun (http://news.detik.com/berita/d-3382743/ kapolda-diy-sepanjang-2016-43-kasuskriminal-didominasi-pelajar).

Tawuran pelajar sebenarnya bukan sebuah fenomena baru karena hampir di semua tempat, terutama di wilayah perkotaan, kasus ini selalu ada. Fenomena tawuran pelajar ini sering kali dilihat sebagai sebuah tindakan yang biasa saja karena tindakan agresivitas ini awalnya merupakan tindakan yang alamiah mengingat usia remaja yang sebenarnya memiliki karakter yang labil, egois, dan mengedepankan kesenangan (Unayah dan Muslim, 2015: 136). Mereka sering menyebut kegiatan tersebut hanya sebagai perlambang keberanian yang membawa kebanggaan bagi pelakunya karena. Namun, sejak adanya kasus tawuran pelajar yang sampai menghilangkan nyawa orang lain masyarakat mulai resah.

Permasalahan tawuran antarpelajar atau klithih yang terjadi di Yogyakarta dapat disebabkan oleh beberapa faktor. Pertama, faktor pola asuh dalam keluarga. Ketidakharmonisan dalam keluarga menyebabkan remaja tidak menemukan kenyamanan dalam keluarga. Kehadiran sosok orang tua yang dapat menjadi teladan juga tidak didapatkan dalam keluarga sehingga perilaku mereka sangat mudah dipengaruhi oleh lingkungan luar. Karakteristik remaja yang ditandai dengan lemahnya kontrol diri menyebabkan mereka tidak dapat membedakan mana tingkah laku yang dapat diterima oleh masyarakat dan mana yang tidak. Ketidakmampuan mengontrol diri ini disebabkan oleh pencarian jati diri pada masamasa remaja, terutama dalam hal identitas peran yang akan mereka bentuk. Oleh masyarakat, mereka dianggap sebagai anak nakal karena gagal mencari jati diri tersebut.

Kedua adalah adanya faktor pergeseran budaya. Perubahan dari masyarakat agraris menjadi masyarakat industri saat ini juga memengaruhi pola asuh terhadap anak. Dalam masyarakat agraris, pola pengasuhan anak lebih menitikberatkan pada keluarga. Hal tersebut berbeda dengan masyarakat industri yang selalu dituntut untuk memenuhi kebutuhan material. Orang tua disibukkan dengan rutinitas pekerjaan yang menyebabkan relasi dalam keluarga menjadi longgar. Oleh karena itu, pola pengasuhan anak bergeser dari yang seharusnya menitikberatkan pada peran keluarga menjadi sepenuhnya diserahkan kepada institutsi pendidikan formal. Tidak heran jika pada masyarakat industri sekarang, tumbuh subur tempat penitipan anak, PAUD, dan sejenisnya. Orang tua merasa lepas tanggung jawab untuk pembentukan karakter setelah anaknya disekolahkan di lembaga pendidikan formal.

Peran sekolah yang sangat kuat tidak ditopang oleh semangat para pendidik dalam mendidik anak didiknya. Relasi antara pihak sekolah dengan orang tua siswa sering kali bersifat sangat formal. Relasi sekolah dengan orang tua siswa pada umumnya terjalin saat penerimaan siswa baru dan pengambilan rapor atau ijazah saja. Saat itu pun yang disampaikan oleh pihak sekolah hanya berupa nilai-nilai akademis semata. Renggangnya relasi antara orang tua dan pihak sekolah juga disebabkan oleh banyaknya orang tua yang tidak terima jika anak mereka didisiplinkan 
oleh guru ketika anaknya dinilai "nakal". Ada juga orang tua yang sampai berurusan dengan pihak kepolisian terkait hal tersebut.

Ketiga adalah pemanfaatan teknologi informasi yang kurang tepat sasaran pada remaja. Pada masyarakat milenial seperti saat ini, informasi apa pun dapat diakses dengan mudah. Remaja sekarang lebih disibukkan dengan aktivitas media sosial dibandingkan dengan bercengkerama langsung dengan keluarga maupun lingkungannya. Dampak dari kondisi ini adalah renggangnya relasi dalam keluarga sehingga dengan mudah remaja mencari sosok dari luar yang menurutnya ideal.

Berdasarkan problematika yang telah disebutkan di atas, maka rumusan masalah dalam tulisan ini adalah bagaimana pola pengasuhan yang ideal dalam keluarga dan sekolah serta bagaimana model relasi yang ideal antarkeduanya dalam menghadapi anak yang terlibat tawuran pelajar di Yogyakarta.
Penelitian ini dilakukan dengan pendekatan mixed methods, yaitu menggabungkan antara pendekatan kualitatif dengan kuantitatif secara bersamaan dengan teknik analisis data deskriptif. Data kualitatif diperoleh dengan melakukan wawancara secara mendalam kepada beberapa pelajar yang pernah terlibat tawuran klithih dan beberapa pelajar yang tidak pernah ikut tawuran. Selain itu, juga dilakukan wawancara kepada orang tuanya dan beberapa guru di SMA yang ada di Yogyakarta serta beberapa anggota masyarakat. Sementara itu, data kuantitatif diperoleh berdasarkan data penelitian "Perubahan Sosial dan Potensi Konflik di Daerah Istimewa Yogyakarta (DIY)" yang dilakukan oleh PSKK UGM bekerja sama dengan Bakesbangpol DIY tahun 2017 dengan jumlah responden sebanyak 7.744 orang.

Penelitian dengan teknik survei mengambil sampel dari seluruh kecamatan, desa/

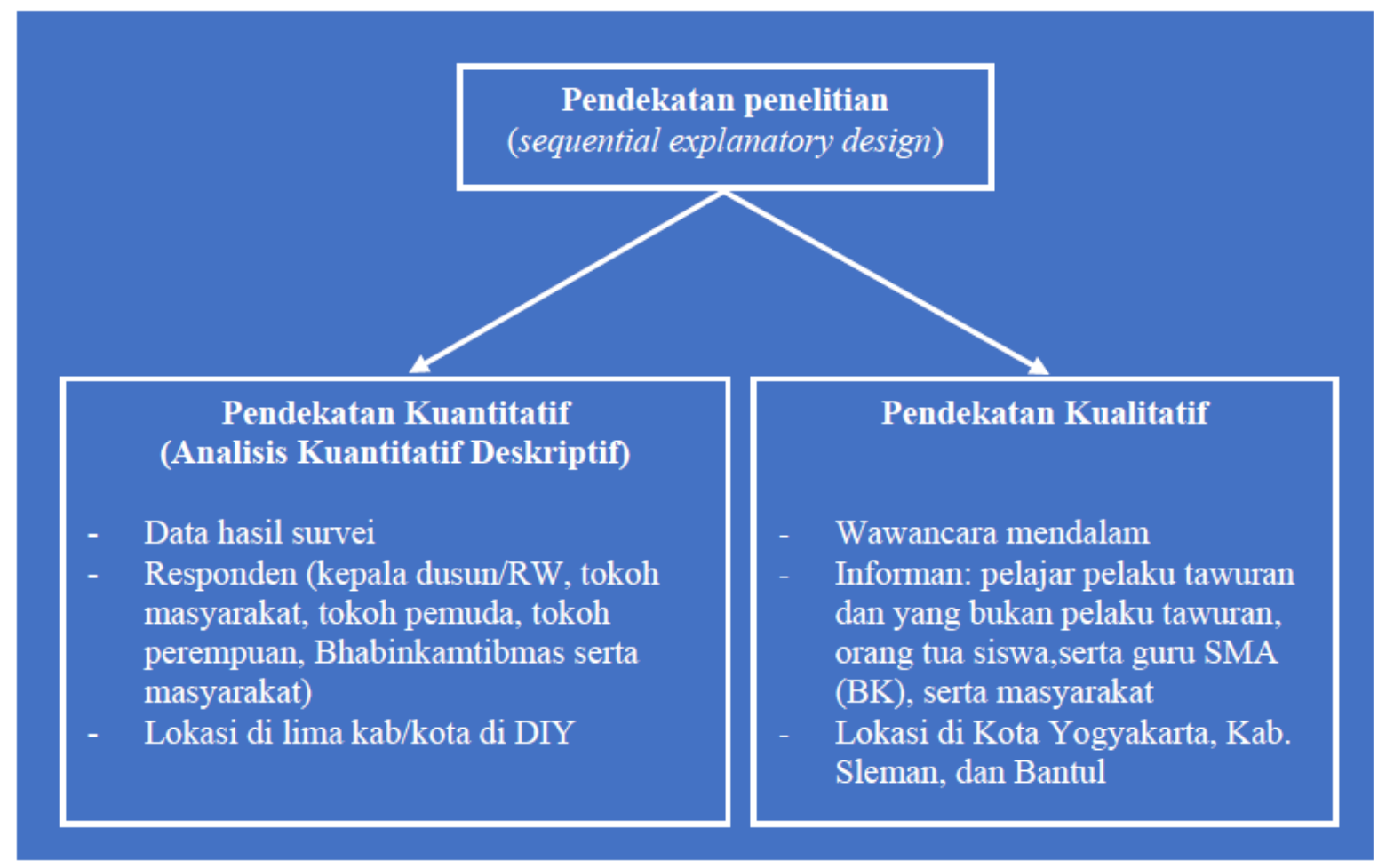

Sumber: PSKK UGM, 2017

Grafik 1 Metode dan Desain Penelitian 
kelurahan, dan pedukuhan/pedusunan/RW yang ada di lima kabupaten/kota di DIY. Pada tingkat kelurahan/desa, diambil enam responden, yang terdiri atas Babinkamtibmas, tokoh perempuan, tokoh pemuda, BPD dan LPMD (atau tokoh lainnya), serta unsur masyarakat. Melalui kriteria tersebut, diharapkan diperoleh informasi dari perspektif aparat kepolisian sebagai unsur pemelihara keamanan dan ketertiban, serta perspektif perempuan, pemuda, dan tokoh masyarakat lainnya. Sementara itu, di tingkat pedukuhan/pedusunan/RW, diambil sampel satu responden, yaitu ketua atau pengurus pedukuhan/pedusunan/RW.

Analisis data kuantitatif ini dimaksudkan untuk melihat persepsi masyarakat DIY terkait keresahan yang timbul akibat maraknya kejadian tawuran antarpelajar. Selain itu, juga analisis tersebut untuk melihat pendapat masyarakat DIY tentang langkah yang harus dilakukan oleh para pemangku kepentingan dalam menangani maraknya tawuran antar pelajar. Berikut adalah desain peneliltian ini (Grafik 1).
Adapun jumlah informan dan topik yang digali dalam wawancara mendalam terdapat dalam Tabel 1.

\section{Pembahasan}

\section{Klithih dalam Lintasan Sejarah Perubahan Sosial}

Aktivitas tawuran antarpelajar di Yogyakarta terkenal dengan sebutan klithih. Awalnya istilah tersebut digunakan warga Yogyakarta untuk menggambarkan aktivitas santai yang tidak ditentukan waktunya. Menurut Suprapto (2017), dosen UGM dan seorang kriminolog, pada 2002-2003 kata yang berasal dari bahasa Jawa tersebut diadopsi oleh anakanak SMP-SMA untuk menyebutkan aktivitas jalan-jalan dan nongkrong di malam hari. Kemudian makna klithih mulai bergeser tahun 2006 dengan adanya sekelompok anak muda bermotor yang saling mengejek dengan pelajar lain dan akhirnya tawuran yang menyebabkan korban luka-luka. Oleh karena itu, pada tahun-tahun selanjutnya

Tabel 1 Jumlah Peserta beserta Topik yang Ditanyakan

\begin{tabular}{lll}
\hline \multicolumn{1}{c}{ Wawancara } & & \multicolumn{1}{c}{ Topik } \\
\hline - Siswa & Persepsi, deskripsi, dan respons terhadap tawuran \\
- Orang tua siswa & antarpelajar di Yogyakarta \\
- Guru bimbingan konseling & - & Pola komunikasi yang terjalin dalam keluarga \\
- Masyarakat & Bentuk dan peran keluarga dalam pola asuh di kelu- \\
& arga \\
& Peran sekolah dalam menangani peserta didik yang \\
& bermasalah \\
& - Sikap orang tua jika anaknya terlibat dalam perkela- \\
& hian antarpelajar \\
& Relasi antara orang tua dan sekolah dalam pe- \\
& nanganan tawuran antarpelajar \\
\hline &
\end{tabular}

Sumber: PSKK UGM, 2017 
klithih memiliki konotasi negatif meskipun tidak populer.

Masyarakat terbiasa menyebut klithih dengan stigma negatif tersebut sekitar tahun 2011-2012 ketika kasus pembacokan remaja sering terjadi (http://jogja.tribunnews. com/2012/01/06/ini-data-tawuran-di-kotayogya). Sederetan kasus tawuran pelajar Yogyakarta selama tahun 2011-2012 adalah antara SMU Gama dengan SMU Bopkri 2 (Jumat, 22/4/2011), Sekolah Menengah Kejuruan (SMK) Piri I dengan SMK Muhammadiyah 3 (Sabtu, 01/10/2011), dan SMA 6 dengan SMA Muhammadiyah 2 (Sabtu, 29/10/2011), serta dua siswa SMA 11 diamankan di Mapolsek Tegalrejo akibat terlibat tawuran di seputaran depan SMA 2 Yogyakarta (Rabu, 14/12). Kemudian media massa mulai gencar menyebut istilah tersebut dalam publikasinya sekitar tahun 2014 (https:// www.gatra.com/nusantara/jawa/250500kapolda-minta-istilah-klithih-dihilangkan). Hingga saat ini klithih menjadi tren tersendiri yang digunakan media maupun masyarakat Yogyakarta untuk menggambarkan fenomena tawuran pelajar.

Mayoritas klithih diwadahi dalam satu geng yang telah turun-temurun di sekolah tersebut. Menurut informan yang membina geng pelajar di daerah Jogokaryan, proses kaderisasi geng pelajar SMA/sederajat dilakukan oleh kakak kelas dan teman seangkatan dengan cara mengajak mereka makan, nongkrong, touring, dan lain sebagainya. Namun, juga terdapat klithih yang murni individu, bukan anak yang tergabung dalam geng, tetapi kasus seperti ini sangat langka ditemukan.

"Setiap sekolah itu memiliki geng, saya pindah ke SMA X ini karena saya tahu ada geng besar di dalamnya. Hidup ini kan, sudah keras, makanya saya masuk geng agar bisa menjalani kerasnya hidup, terlatih gitu lo ... dan tidak mudah kaget melihat apa pun - darah saat ada kecelakaan, mbleyer, dicurangi orang lain --, makanya menurut saya, masuk geng itu merupakah hal yang perlu dilewati, tapi tidak diulangi ketika sudah selesai SMA".

Embrio geng remaja di Yogyakarta diawali pada 1970-an dari sebuah klub minicross, yaitu sepeda jenis mini dan jengki yang telah dimodifikasi (Jatmiko, 2010: 50-59). Kegiatan klub itu adalah seputar memodifikasi sepeda, pamer keterampilan bersepeda, pelah cross (lomba mendorong velg sepeda yang telah dilepas jerujinya lantas didorong dengan kayu), dan balapan sepeda. Para anggotanya adalah mereka yang berpakaian rapi dan terpelajar (Jatmiko, 2010: 59). Untuk menjadi anggota klub, mereka akan diuji melakukan jumping setinggi dua meteran, berstatus pelajar, dan mendaftar untuk mendapatkan kartu anggota (Jatmiko, 2010: 50-51). Karena persyaratan yang tidak mudah tersebut, anggota klub sepeda di masa itu terkesan elite dan borjuis.

Klub minicross dibentuk dengan tujuan untuk olahraga, serta simbol dari kekompakan, keberanian remaja yang berstatus pelajar, dan ekspresi sosial remaja kalangan menengah ke atas untuk menunjukkan eksistensinya. Klub di masa itu sama sekali tidak mengarah kepada afiliasi partai politik tertentu yang akan ditemukan pada 1980-an.

Terdapat sekitar 66 klub minicross pada akhir 1970-an hingga awal 1980-an yang di antaranya adalah Marabunta (Manusia Raja Bunderan Yogyakarta), Cepethe (Cepet Pegun Themon), Derex (Depan Regol Xauman), KPX (Keproex), dan Gaplay Fox (Gabungan Anak Play Boy Fersi Orang Xolot) (Jatmiko, 2010: 54-56). Banyaknya nama klub minicross ini menunjukkan bahwa hampir setiap kampung di Yogyakarta memiliki klubnya sendiri. Sementara 
itu, untuk menunjukkan keberadaannya, mereka membuat aksi coret-coret yang memenuhi tembok menggunakan kapur, arang atau alatalat murah yang dapat digunakan untuk menulis (Wicandra, 2016: 52).

Kemudian pada awal 1980-an, muncullah sepeda jenis BMX yang sebagian besar anggotanya berasal dari kalangan menengah ke bawah dan bukan pelajar. Akibatnya, klub yang awalnya bernuansa simpatik perlahan mengarah ke sikap premanisme: kekerasan dan tawuran (Jatmiko, 2010: 71). Hal inilah yang menggeser istilah "klub" menjadi "geng". Namun, pada 1982-1985 (Sudjatmoko, 2016: 331) petrus (penembak misterius) sedang marak terjadi di Indonesia sehingga anggota geng tidak berani unjuk nyali karena jika ketahuan, mereka akan langsung ditembak tanpa diproses hukum.

Pasca peristiwa petrus muncul banyak fenomena di masyarakat yang di antaranya (Jatmiko, 2010: 70-79) adalah sebagai berikut. Pertama, geng kembali menguat yang ditandai dengan semakin banyaknya geng motor remaja di Yogya yang sebagian merupakan alumni dari klub minicross ataupun BMX. Sementara itu, sebagiannya lagi berasal dari geng motor legendaris yang telah ada sejak awal 1980, yaitu Joxzin (Joxo Zinthing) dan Qizruh (Q-ta Zuka Ribut untuk Hiburan).

Kedua, pada era 1980-an juga terjadi pergeseran pola tawuran yang sebelumnya terjadi antarkampung atau antarmahasiswa dengan motif sportif dan untuk mengukur keberanian remaja. Biasanya tawuran dilakukan satu lawan satu kemudian setelah selesai, mereka akan bersalaman dan berangkulan. Namun yang terjadi kemudian adalah pola ndingkik, yaitu menusuk lewat belakang, keroyokan, dan pencegatan terhadap mereka yang dianggap lawan. Ketiga, dari segi asal pelaku dan tempat bergerombol, geng remaja juga mengalami pergeseran dari sebelumnya geng remaja jarang berdasar sekolahan menjadi geng yang berdasarkan nama sekolah SMA. Keempat, klub atau geng remaja yang sebelumnya bersifat nonpolitis menjadi mengarah kepada partai politik.

Tahun 1990-an Joxzin dan Qizruh meluaskan wilayah pengaruhnya ke sekolah setingkat SMA. Dari ekspansi tersebut, muncullah nama-nama geng pelajar, di antaranya adalah Oestad, Ranger, Morenza, Respect, LBD, Hippies, Pastoer, dan GNB (Jatmiko, 2010: 89). Aktivitas rutin masa ini adalah nongkrong, coret-coret menggunakan cat semprot, dan pada 2000-an kegiatannya bertambah dengan ngenet (bermain internet).

Memasuki tahun 2000-an Joxzin dan Qizruh sebagai dua geng utama di Yogyakarta melakukan ekspansi besar-besaran tidak hanya ke sekolah setingkat SMA, tetapi juga setingkat SMP. Beberapa geng SMP yang ada adalah ZNC, Ezphero, Dekrizo, ZKD, Spenyk, BTV, Zareta, dan Libaz. Selain itu, marak juga muncul beberapa geng yang beranggotakan murid perempuan, di antaranya adalah CeMazint, Bricex, B7NGAN 4YO3, dan CeQizhm CeRiezt (Jatmiko, 2010: 100-101). Tahun 2000-an ini geng pelajar yang sebelumya melakukan klithih hanya kepada lawannya saja mulai bergeser dengan menyasar masyarakat biasa yang tidak memiliki masalah dengan anggota geng tersebut. Tujuannya adalah untuk menunjukkan eksistensi diri di dalam kelompok. Kondisi inilah yang membuat pelaku semakin berani, sadis, dan tega melukai orang lain akan mendapatkan posisi tinggi dalam geng tersebut.

Pergeseran istilah dan makna klithih dan klub-geng menjadi sangat kompleks seiring dengan perubahan sosial yang terjadi. Menurut Sari Murti selaku Ketua Lembaga Perlindungan Anak (LPA) Yogyakarta, kasus 
klithih lima tahun terakhir ini secara kuantitas berkurang, tetapi secara kualitas, semakin sadis. Klithih yang bermula dari jalan-jalan santai berubah menjadi sebuah aktivitas yang berujung pada penghilangan nyawa. Begitu juga dengan geng yang berawal dari perkumpulan pelajar yang memiliki hobi bersepeda berubah menjadi perkumpulan remaja yang bertindak premanisme.

\section{Maraknya Tawuran Pelajar sebagai Pertanda Perkembangan Suatu Wilayah}

Berdasarkan gambaran perjalanan pembentukan gang pelajar beserta rekam jejaknya di atas, salah satu hal yang menjadi keprihatinan bersama adalah kasus tawuran pelajar yang justru semakin menjurus pada tindakan kriminalitas dan berujung pada penghilangan nyawa orang lain. Berdasarkan dari data Survei Perubahan Sosial dan Potensi Konflik tahun 2017, masyarakat Yogyakarta menyatakan 66 persen tindakan kekerasan kelompok, terutama aksi klithih meningkat, sedangkan 11 persen masyarakat menyatakan tetap, 15 persen masyarakat menyatakan menurun, dan 8 persen masyarakat menyatakan tidak tahu.

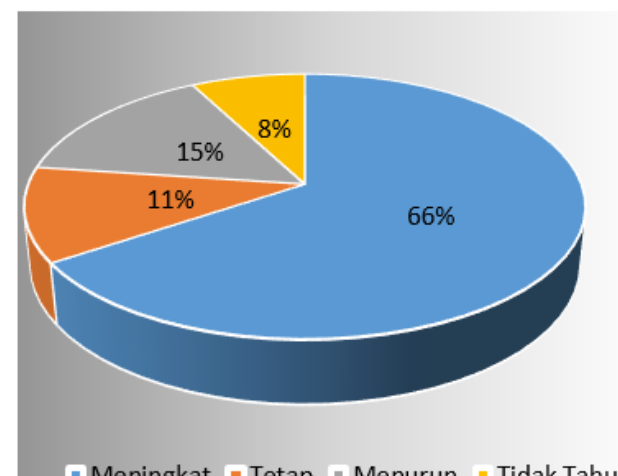

- Meningkat - Tetap - Menurun - Tidak Tahu

Sumber: PSKK UGM, 2017
Persepsi masyarakat terhadap peningkatan aksi kekerasan kelompok disebabkan oleh maraknya pemberitaan yang dilakukan oleh media massa, terutama melalui media sosial. Pemberitaan ini menjadi masif karena predikat Yogyakarta sebagai kota pelajar, kota budaya, dan kota pariwisata yang seharusnya lekat dengan sopan santun, kelembutan dan keramahtamahan, tetapi yang muncul justru sebaliknya.

Tindakan tawuran pelajar tidak dapat dilepaskan dari perkembangan sebuah wilayah. Umumnya kasus seperti ini muncul di wilayah perkotaan maupun daerah penyangga perkotaan. Hasil dari data survei juga menunjukkan hal tersebut. Peneliti survei ini menggali data dengan menanyakan kepada masyarakat terkait keberadaan sekolah yang siswanya sering melakukan tawuran pelajar. Hasilnya memperlihatkan 14,8 persen masyarakat Kota Yogyakarta menyatakan bahwa sekolah di wilayahnya (dalam 1 kelurahan/desa) terlibat tindakan tawuran pelajar, kemudian 9,1 persen untuk Kabupaten Bantul, 8,2 persen untuk Kabupaten Sleman, 2,3 persen untuk Kabupaten Kulonprogo, dan 0,5 persen untuk Kabupaten Gunungkidul.

Grafik 2 Pendapat Masyarakat Terkait Tindakan Kekerasan di Yogyakarta 


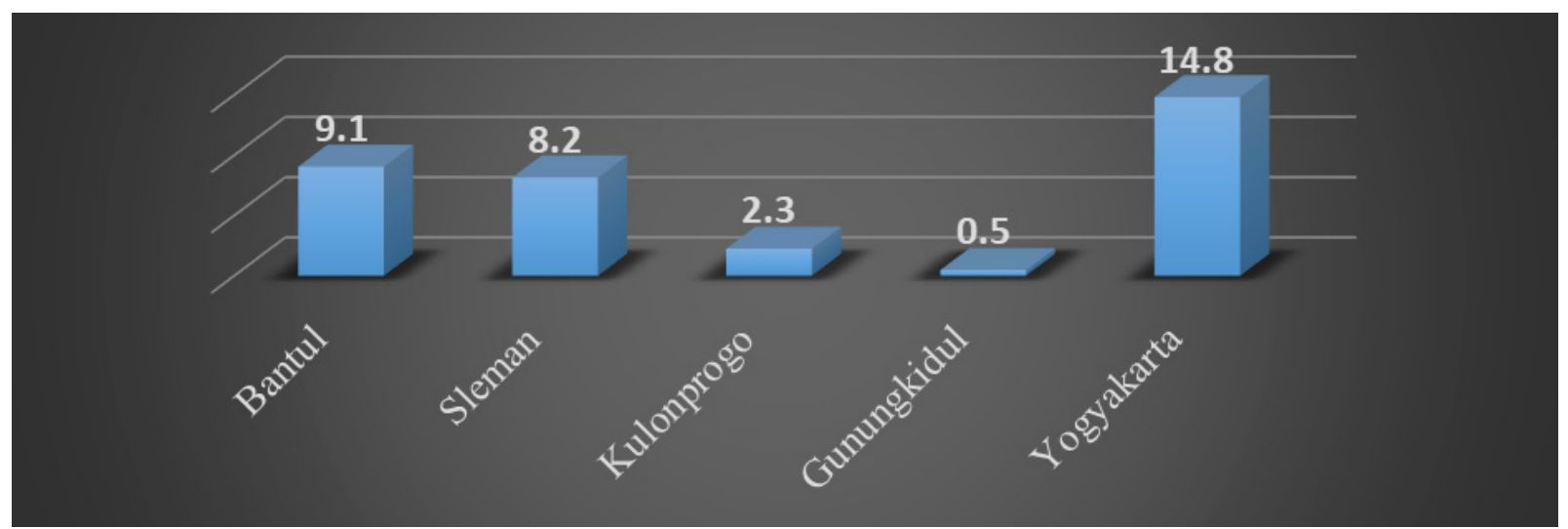

Sumber: PSKK UGM, 2017

Grafik 3 Keberadaan Sekolah yang Siswanya Sering Melakukan Tawuran Pelajar menurut Kabupaten/Kota

Data di atas memperlihatkan bahwa tindakan tawuran antarpelajarumumnyaterjadi di wilayah perkotaan atau semiperkotaan, sedangkan wilayah yang mayoritas perdesaan, seperti di Kabupaten Gunungkidul dan Kulonprogo, mempunyai persentase yang kecil. Berdasarkan teori Differential Opportunity System yang dikemukakanan oleh R.A. Cloward dan L.E. Ohlin (dalam Sarwirini, 2011: 247-248), penyimpangan di suatu wilayah perkotaan merupakan fungsi dari perbedaan kesempatan yang dimiliki anak-anak untuk mencapai tujuan yang legal maupun yang ilegal. Manakala kesempatan untuk memperoleh yang legal terblokir, maka tindak kriminal pun mungkin terjadi sehingga kecenderungan keterlibatan pada penggunaan narkotika atau dengan kekerasan juga dapat terjadi. Subbudaya yang mungkin terjadi, menurut Cloward dan Ohlin, dikelompokkan menjadi tiga bentuk. Pertama adalah criminal sub-cultur, yaitu bentuk-bentuk perilaku geng yang ditujukan untuk kepentingan pemenuhan uang atau harta benda. Kedua adalah conflict sub-cultur, yaitu bentuk geng yang berusaha mencari status menggunakan kekerasan. Ketiga adalah reatreatist sub-cultur, yaitu bentuk geng dengan ciri-ciri penarikan diri dari tujuan dan peranan konvensional kemudian mencari pelarian dengan menyalahgunakan obat atau narkotika atau sejenisnya.

Kasus kekerasan geng sekolah juga dipengaruhi oleh peran teman sebaya dan peran alumni. Hasil wawancara mendalam dengan salah satu mantan anggota geng sekolah swasta di Yogyakarta menyebutkan bahwa awal mula ia mengikuti geng adalah karena dorongan dari teman-temannya. Mengikuti geng menjadi sebuah keharusan sebagai wujud aktualisasi diri. Faktor kakak kelas dan alumni juga merupakan faktor kunci untuk mendorong anggota geng melakukan aksi kekerasan (Anjari, 2012: 35). Aksi kekerasan ini diharapkan dapat menjadikan geng mereka lebih populer dan disegani walaupun harus melukai, bahkan sampai membunuh orang lain. Doktrin dari kakak kelas dan alumni menyebabkan siswa percaya bahwa hal tersebut benar.

Status tinggi dalam geng sekolah didasarkan pada anggota geng yang paling berani dan sadis. Untuk itu, tidak jarang saat melakukan aksi tawuran atau aksi yang lain, mereka dengan sadar merekamnya dalam bentuk video atau minimal menyampaikannya 
dalam media sosial (terutama pada grup whatsapp kelompok mereka).

Berdasarkan hasil wawancara dengan salah seorang informan yang pernah menjadi pimpinan gang pelajar di era 1990-an (geng Joxzin) dan sekarang menjadi pembina geng pelajar, pergeseran motif pelaku tawuran lebih pada faktor pencarian status dalam kelompok geng tersebut atau yang disebut dengan golek alem. Oleh karena itu, dalam era digital saat ini peran media sosial, terutama Facebook, youtube, dan whatsapp, sangat penting.

Maraknya penggunaan media sosial tersebut tidak dapat dilepaskan dengan pergeseran budaya sebagai dampak dari perkembangan teknologi informasi. Generasi saat ini, terutama pelajar SMA, sangat lekat dengan mobile internet, bahkan telah masuk dalam kategori ketergantungan. Lekatnya mereka dengan gawai ditenggarai sebagai salah satu penyebab masifnya aksi klithih di Yogyakarta.

"Saya pernah lihat sendiri, anak didik saya sedang asik menggerombol lihat video tawuran. Mereka seperti termotivasi dengan aksi-aksi tawuran yang di-upload di video terutama alat yang digunakan dalam aksi tawuran" (informan pembina geng pelajar di Yogyakarta).

Menurut pakar demografi, Cohort, generasi yang lahir tahun 1981 - 2000 atau sekarang yang berusia 16 - 36 tahun masuk dalam kategori generasi milenial (dalam Ali, dkk.,
2016: 13-15). Ciri utama generasi milenial itu adalah tingkat keterpaparan mereka pada sosial media, meluasnya internet, dan munculnya ponsel pintar. Ketiga hal tersebut sangat memengaruhi pola pikir, nilai, dan perilaku yang dianut.

Dalam menghadapi generasi milenial ini, maka yang perlu diperhatikan adalah cara memanfaatkan teknologi informasi agar lebih banyak memberikan nilai positif dibandingkan dengan negatifnya. Guna menghindari dampak negatif yang muncul, perlu ditanamkan pondasi yang kuat dalam keluarga, terutama dalam hal pengasuhan. Tidak jarang terlihat bahwa meskipun secara fisik, orang tua dekat dengan anak, tetapi yang terjadi adalah mereka berjauhan karena kurangnya perhatian satu sama lain. Mereka asyik dengan dirinya sendiri sambil memainkan ponsel pintarnya. Ciri khas inilah yang muncul dalam kehidupan nyata seharihari. Hal yang sama juga terjadi dalam relasi sosial pada masyarakat yang telah mulai renggang akibat dari ketergantungan mereka pada ponsel pintar.

Relasi sosial secara tatap muka dengan masyarakat di lingkungan kurang begitu terasa jika dibandingkan dengan relasi secara digital. Dampak yang nyata dari kehidupan yang mulai berubah ini adalah hilangnya peran masyarakat dalam mengontrol anggota dalam masyarakat tersebut. Jika dulu masih dapat terlihat tetangga yang menegur tetangganya karena anaknya berperilaku menyimpang, saat ini hal itu jarang terjadi.

Tabel 2 Teori Cohort tentang Phase of Demographic Group

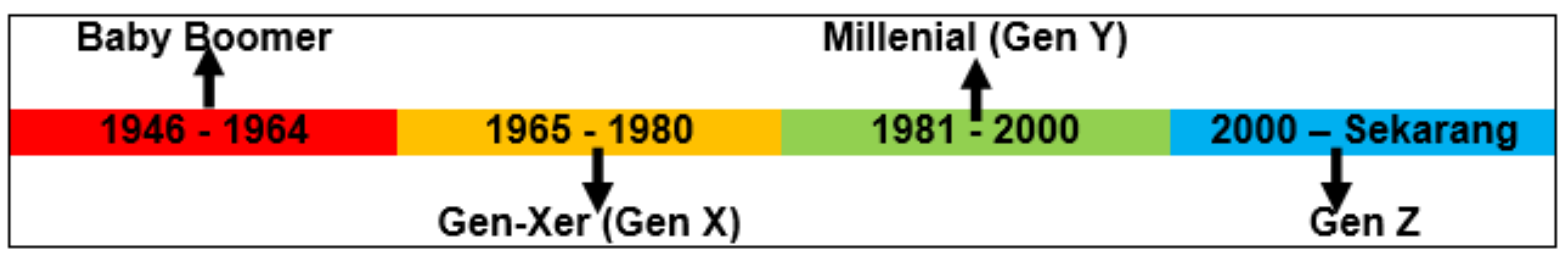

Sumber: Cohorts dalam Ali, 2016. 
Tabel 3 Pergeseran Budaya dalam Relasi Sosial

\begin{tabular}{|c|c|c|c|c|}
\hline Pergeseran Budaya & Pertanian & Industri & Milenial & \\
\hline Relasi dalam keluarga & Kuat & Lemah & Sangat lemah & \\
\hline Relasi sosial/lingkungan & Kuat & Mulai memudar & $\begin{array}{lr}\text { Sangat } & \text { lemah } \\
\text { dekat } & \text { dengan } \\
\text { maya) } & \end{array}$ & $\begin{array}{l}\text { (lebih } \\
\text { dunia }\end{array}$ \\
\hline
\end{tabular}

Sumber: Hasil Analisis, 2017

Peran Orang Tua (Keluarga) dalam Pengasuhan Anak pada Generasi Milenial

Pendidikan keluarga adalah pendidikan pertama yang didapatkan oleh seorang anak. Sifat dan perilaku seorang anak ditentukan oleh pembelajaran pertama mereka yang melibatkan keluarga. Oleh karena itu, keluarga, khususnya orang tua, memiliki peran utama dalam pembentukan mental seorang anak. Peran orang tua terhadap anak di dalam keluarga adalah sebagai motivator. Orang tua harus senantiasa memberikan dorongan terhadap anak untuk berbuat kebaikan, termasuk dalam hal menuntut ilmu pengetahuan. Peran selanjutnya adalah sebagai fasilitator. Orang tua harus senantiasa memberikan fasilitas bagi kebutuhan anak yang berupa sandang, pangan, dan papan, termasuk kebutuhan pendidikan. Selanjutnya orang tua harus dapat menjadi mediator yang bertindak sebagai mediasi dalam hubungan kekeluargaan dan kemasyarakatan, terutama hubungan dengan sekolah (Makmun dan Abin, 1999: 40-43).

Peran orang tua dalam hal pendidikan anak telah seharusnya berada pada urutan pertama. Hal itu karena orang tualah yang paling mengerti sifat baik dan buruk seorang anak, termasuk hal yang mereka sukai dan tidak sukai. Hasil wawancara mendalam dengan salah satu orang tua siswa SMA favorit di Yogyakarta menyatakan bahwa ketika anak telah menginjak usia remaja, maka peran orang tua dalam pembelajaran harus ditingkatkan dari segi pengawasan dan pengarahan secara rutin. Orang tua juga harus selalu memantau perkembangan kepribadian yang mencakup sikap, moral, dan tingkah laku anak di lingkungan sekolah dengan selalu berkomunikasi dengan wali kelas. Usia remaja merupakan masa transisi seseorang dari anak-anak menuju dewasa dengan kondisi emosi jiwa yang sangat labil. Berbagai perubahan akan tampak pada masa itu, termasuk dalam cara berpikir ketika seorang anak remaja akan berusaha menunjukkan siapa dirinya, cenderung egois, dan ingin terlihat 'lebih'di lingkungannya. Ketika seorang anak mulai ingin menunjukkan eksistensinya, maka orang tua harus mengarahkan ke jalur yang benar. Salah satunya adalah ke ranah akademik sehingga seorang anak akan lebih dikenal karena prestasinya.

Remaja yang tidak diarahkan oleh orang tuanya akan lepas kontrol dan cenderung berbuat semaunya. Hasil wawancara dengan beberapa orang tua siswa SMK di Yogyakarta menunjukkan bahwa lemahnya kontrol orang tua sangat berpengaruh pada anak. Salah satu orang tua siswa pelaku tawuran menyebutkan bahwa ia memberikan kebebasan bagi anaknya untuk melanjutkan sekolah atau mau langsung bekerja. Ketika anak memilih bersekolah, orang tua juga memberi kebebasan kepada anaknya dalam 
memilih sekolah. Orang tua juga tidak mengetahui dengan siapa anaknya bergaul sehari-hari. Orang tua siswa yang lain, bahkan tidak mengetahui aktivitas anaknya di sekolah karena bagi mereka, yang penting adalah dapat membiayai sekolah dan kenyataan bahwa si anak berangkat sekolah. Hal ini disebabkan oleh adanya tuntutan kemandirian dari orang tua kepada anaknya. Lemahnya kontrol orang tua pada masa pencarian jati diri seorang remaja mengakibatkan perilaku remaja tersebut sangat mudah dipengaruhi oleh lingkungan luar yang tentu saja lebih banyak dampak negatifnya.

Proses pencarian jati diri yang tidak diarahkan oleh orang tua akan menyebabkan ketidakmampuan remaja dalam mengontrol diri sehingga gagal memilih cara untuk menunjukkan eksistensinya. Sifat remaja yang labil dan mudah goyah menyebabkan mereka mudah merasa minder dan malu jika tidak mengikuti arus perkembangan zaman dan akan menjadi objek persekusi teman sebayanya. Oleh karena itu, untuk membuktikan eksistensinya, remaja berinisiatif mencoba hal yang dianggapnya sesuai dengan perkembangan zaman tanpa memedulikan dampaknya. Remaja masa kini yang hidup dalam kehidupan modern dan global sangat mudah mendapatkan akses terhadap banyak hal. Hal ini dapat menyebabkan remaja mudah terjerumus dalam pergaulan modern yang mengarah pada tindakan negatif (Basri, 1996: 57).

Pernyataan tersebut sejalan dengan hasil temuan data yang menyatakan bahwa tindakan negatif yang dilakukan oleh pelajar dalam bentuk tawuran sangat dipengaruhi oleh lemahnya peran orang tua (65,7 persen), salah pergaulan (52,5 persen), lemahnya peran sekolah (36,2 persen), dan faktor narkoba (30,8 persen) sebagaimana yang digambarkan dalam Grafik 4.

Lemahnya peran orang tua dalam pengasuhan pada era generasi milenial disebabkan oleh terputusnya pola komunikasi antara anak dan orang tua. Berdasarkan dari teori Cohort, orang tua yang memiliki anak usia SMA sekarang ini umumnya berasal dari era Gen-Xer atau generasi X. Mereka adalah generasi yang masih memiliki pola pikir konservatif meskipun telah masuk era transisi modernisasi teknologi informasi (Ali, 2016: 15). Terputusnya pola komunikasi inilah yang menyebabkan kehadiran orang tua kurang dirasakan oleh anak. Relasi sosial dalam

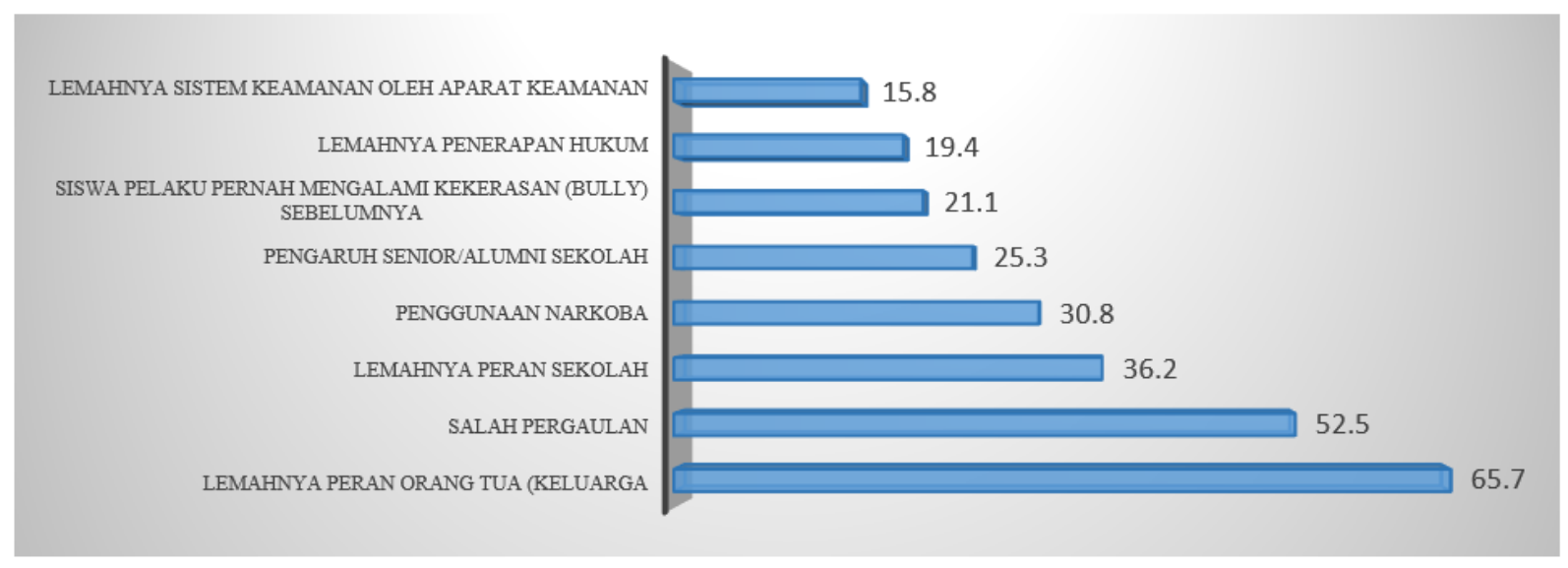

Sumber: PSKK UGM, 2017

Grafik 4 Pendapat Masyarakat terhadap Munculnya Tawuran Pelajar di Yogyakarta 
keluarga dalam era digital sangat tergantung pada penggunaan ponsel pintar. Sering kali komunikasi antara orang tua dengan anak tidak dilakukan secara tatap muka, tetapi digantikan dengan ponsel pintar (komunikasi tak langsung). Pola komunikiasi dalam keluarga yang seperti ini pasti menimbulkan perbedaan dalam interaksinya karena lebih individualis. Dampak dari pola interaksi ini adalah tidak terjalinnya kedekatan emosional antara orang tua dan anak.

Peran orang tua mutlak diperlukan dalam membimbing dan memberikan perhatian pada anak. Orang tua harus menemani, memantau, dan mengarahkan remaja agar mereka dapat melewati masa labil dan terhindar dari pengaruh negatif. Hal ini sesuai dengan data hasil survey yang menunjukkan bahwa 25,3 persen masyarakat menyatakan penanganan tawuran pelajar dilakukan dengan meningkatkan peran keluarga, terutama orang tua. Sementara itu, 18 persen masyarakat berpendapat penanganan tawuran pelajar dilakukan dengan cara memberikan pembinaan kepada siswa yang dilakukan oleh sekolah dan masyarakat. Pendapat masyarakat yang lain adalah dengan menanamkan pendidikan agama dan budi pekerti (13,4 persen), serta peningkatan kesadaran dan penerapan hukum secara tegas (11,7 persen).

Peningkatan peran keluarga pada era digital dapat dilakukan dengan beberapa cara. Misalnya adalah orang tua harus melek teknologi, terutama internet karena yang terjadi saat ini adalah orang tua dianggap ketinggalan zaman atau kolot karena tidak mengenal internet. Tidak jarang, bahkan orang tua belajar internet dari anak-anak mereka. Dampak dari ketidaktahuan orang tua terhadap teknologi informasi itu menyebabkan mereka tidak mengetahui situs yang diakses oleh anak dan teman bergaul anak di dunia maya. Anak pun sekarang lebih banyak curhat lewat media sosial dibandingkan dengan bicara langsung ke orang tua.

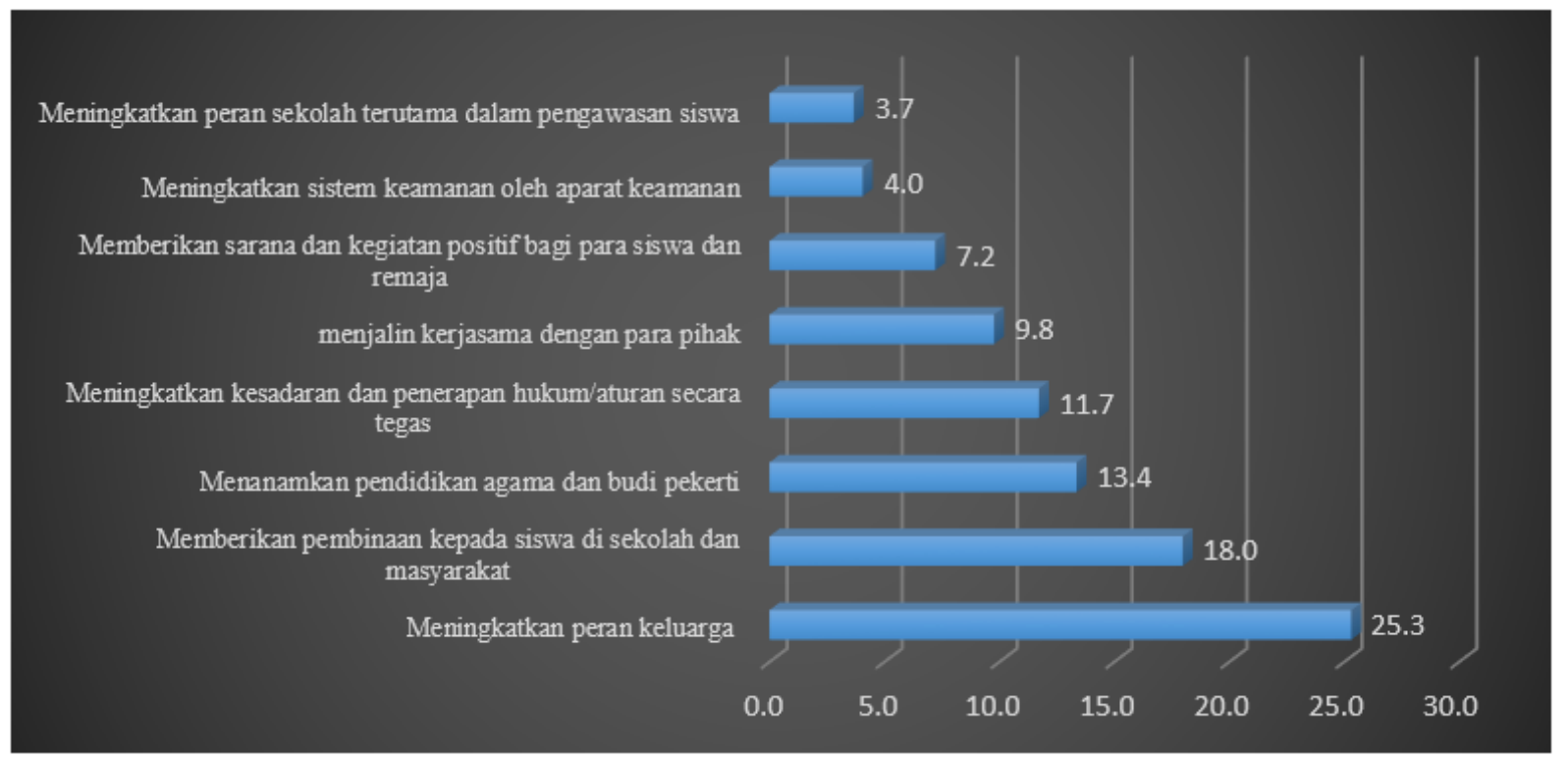

Sumber: PSKK UGM, 2017

Grafik 5 Pendapat Masyarakat terhadap Penanganan

Masalah Tawuran Pelajar di Yogyakarta 
Upaya Membangun Relasi Digital antara Siswa, Orang Tua, dan Sekolah

Sekolah sebagai institusi pendidikan formal tidak saja memiliki fungsi pengajaran, tetapi juga mengemban fungsi pendidikan. Salah satu komponen pendukung keberhasilan sekolah dalam menjalankan fungsi pendidikan adalah adanya guru yang dapat membangun komunikasi yang baik dengan siswa dan orang tua siswa (Hidayat, 2013: 92). Komunikasi yang efektif dan akrab antara guru dan siswa telah mulai dibangun oleh salah satu SMA melalui FKGM (Forum Komunikasi Guru dengan Murid). Melalui forum ini, diharapkan siswa dapat merasakan kenyamanan untuk berbagi dengan guru. Rasa nyaman itu akan berdampak pada keterbukaan siswa. Hal yang sama juga telah diterapkan oleh dua SMA lain dalam rangka menangani kasus tawuran dan klithih. Pendekatan personal dengan siswa akan sangat bermanfaat dalam memahami keinginan sebenarnya yang dimiliki oleh siswa.

Pihak sekolah juga diharapkan mampu menjalin relasi yang baik tidak hanya dengan siswa saja, tetapi juga dengan orang tua siswa. Relasi yang baik antara orang tua siswa dengan sekolah dapat dimulai dari awal proses seleksi siswa melalui wawancara dengan orang tua (Baedowi, dkk., 2015: 66). Proses ini telah diterapkan juga di salah satu SMA sebagai tahap awal membangun relasi dengan orang tua dan untuk mengenal karakter siswa. Wawancara merupakan alat seleksi yang cukup penting dan proses bertukar informasi yang baik (Rohmawati, 2015: 15-16). Melalui wawancara antara sekolah dengan orang tua, diharapkan akan terbangun komunikasi awal yang baik. Lebih lanjut proses wawancara dapat digunakan sebagai momentum penyatuan pemikiran bahwa mendidik siswa merupakan tanggung jawab bersama antara sekolah dengan orang tua. Proses wawancara dengan orang tua juga akan memberikan informasi mengenai karakteristik siswa yang akan bermanfaat bagi sekolah dalam memahami siswa yang bersangkutan. Proses ini juga dapat memberikan gambaran visi dan misi sekolah kepada orang tua sehingga orang tua memahami program-program sekolah. Pemahaman yang baik terhadap program sekolah akan membantu orang tua berpartisipasi dalam kegiatan-kegiatan sekolah.

Hasil penelitian menunjukkan bahwa proses penerimaan siswa yang disertai wawancara dengan orang tua dinilai mampu menjadi salah satu cara dalam menangani kenakalan siswa (hasil wawancara mendalam dengan guru BK salah satu sampel SMA, 20 Juli 2017, pukul 07.16 WIB). Proses wawancara yang dilakukan akan memberikan informasi kepada pihak sekolah mengenai riwayat siswa yang bersangkutan. Informasi apakah siswa yang bersangkutan pernah terlibat kasus kekerasan atau tidak akan sangat bermanfaat untuk mengantisipasi hal tersebut terulang kembali di SMA. Ketika informasi ini telah diketahui oleh pihak sekolah, maka pihak sekolah dapat melakukan tindakan-tindakan pencegahan, seperti dengan melakukan pengawasan lebih kepada siswa yang bersangkutan dan melaksanakan komunikasi rutin dengan pihak orang tua siswa.

Proses seleksi masuk dengan wawancara terhadap orang tua dan siswa serta tes psikologi telah diterapkan di salah satu SMA yang tidak memiliki riwayat kasus kekerasan. Hasil tes psikologi dibahas juga dengan orang tua siswa sebagai dasar menentukan arah program pengembangan siswa di sekolah. Orang tua dapat juga memahami potensi anak mereka tanpa harus memaksakan kehendaknya kepada anak. Hal ini sangat 
penting karena pola asuh yang otoriter hanya akan berdampak negatif terhadap anak. Anak dengan pola asuh otoriter akan memiliki karakteristik suka melanggar norma, gemar menantang, berkepribadian lemah, dan menarik diri dari lingkungan sekitar (http://staffnew.uny.ac.id/upload/132309077/ penelitian/ARTIKEL+POLA+ASUH.pdf).

Studi literatur menunjukkan bahwa proses pendidikan yang efektif membutuhkan beberapa konsekuensi, salah satunya terkait dengan partisipasi orang tua. Manfaat dari partisipasi efektif orang tua pada berbagai kegiatan sekolah adalah akan meningkatkan prestasi akademik siswa, menyebabkan siswa berperilaku positif, mengurangi sikap anti sosial siswa, dan menjamin keberlangsungan studi siswa ke jenjang yang lebih tinggi (Vahedi, 2010: 359-360).

Salah satu faktor yang memengaruhi keberhasilan pencegahan dan penanganan kasus kekerasan siswa adalah harmonisasi komunikasi antara sekolah dengan orang tua. Guru sebagai orang tua siswa di sekolah tidak boleh hanya berkomunikasi dengan orang tua siswa ketika awal tahun ajaran baru dan saat pembagian rapor saja. Pertemuan-pertemuan tatap muka maupun komunikasi berbasis teknologisangatpentinguntukdilakukandalam rangka mengomunikasikan perkembangan siswa. Melalui komunikasi tersebut juga, pihak sekolah dapat mengedukasi orang tua terkait cara memperlakukan anaknya yang telah remaja sehingga tidak terjadi kesalahpahaman antara orang tua dengan anak. Sebaliknya, pihak orang tua juga dapat memberikan informasi terkait kondisi anak di rumah. Komunikasi dua arah semacam inilah yang dapat dijadikan salah satu cara dalam mengatasi fenomena kekerasan/tawuran siswa SMA (Basri, 2015: 22). Hasil penelitian menunjukkan bahwa umumnya beberapa SMA di Kota Yogyakarta telah mengadakan pertemuan-pertemuan dengan orang tua siswa, tetapi masih terdapat beberapa SMA yang mengadakan pertemuan tersebut terbatas pada awal tahun ajaran dan saat penerimaan rapor. 
Tabel 4 Perbandingan Nilai yang Dikembangkan Sekolah antara Sekolah yang Memiliki Budaya Kekerasan dengan yang Tidak Memiliki Budaya Kekerasan

\begin{tabular}{|c|c|c|}
\hline SMA & Budaya Kekerasan & Nilai/ Upaya Pencegahan/ Upaya Penanggulangan \\
\hline SMAA & Tidak ada & $\begin{array}{l}\text { - Proses seleksi masuk siswa dilaksanakan dengan } \\
\text { ketat dan disertai wawancara dengan orang tua siswa } \\
\text { - Memfasilitasi kreativitas siswa dengan berbagai ke- } \\
\text { giatan ekstrakurikuler } \\
\text { - Kegiatan bela negara dengan Rindam sebagai } \\
\text { rangkaian Pengenalan Lingkungan Sekolah (PLS) } \\
\text { - Komunikasi yang erat antara sekolah dengan orang } \\
\text { tua siswa (pertemuan tatap muka, presensi berba- } \\
\text { sis teknologi yang terintegrasi dengan ponsel orang } \\
\text { tua siswa), pengajian }\end{array}$ \\
\hline SMA B & Tidak ada & $\begin{array}{l}\text { - Menjalin komunikasi efektif dan akrab antara guru } \\
\text { dengan siswa melalui FKGM (Forum Komunikasi } \\
\text { Guru Murid) } \\
\text { - } \text { Menjalin komunikasi dengan orang tua siswa mel- } \\
\text { alui pertemuan-pertemuan, grup WA } \\
\text { - } \text { Memiliki Tim Kominfo yang bertugas memberikan } \\
\text { informasi dan melayani pertanyaan-pertanyaan } \\
\text { orang tua siswa melalui media sosial } \\
\text { - Presensi menggunakan sidik jari yang terintegra- } \\
\text { si dengan nomor ponsel orang tua (saat ini hanya } \\
\text { sidik jari biasa) } \\
\text { - Pemasangan CCTV di berbagai tempat } \\
\text { - Pembinaan dari lembaga anti teror, kepolisian, } \\
\text { psikolog, PKBI, dll. } \\
\text { - Presensi menggunakan kartu (sekarang tidak digu- } \\
\text { nakan lagi) }\end{array}$ \\
\hline SMA C & $\begin{array}{l}\text { - Penyerangan sis- } \\
\text { wa SMA swasta } \\
\text { - Senioritas }\end{array}$ & $\begin{array}{l}\text { - Pendekatan personal tanpa menyalahkan dan tidak } \\
\text { mengeluarkan siswa yang terlibat kasus kekerasan } \\
\text { (membangun saling percaya antara siswa dengan } \\
\text { guru) } \\
\text { - } \text { Memberlakukan penghapusan negative point den- } \\
\text { gan poin prestasi } \\
\text { - Pendekatan dengan orang tua melalui per- } \\
\text { temuan-pertemuan, komunikasi melalui ponsel, } \\
\text { kunjungan rumah, pengajian kelas } \\
\text { - } \text { Menyediakan berbagai jenis ekstrakulikuler } \\
\text { - Menjalin komunikasi dengan masyarakat sekitar } \\
\text { lingkungan sekolah } \\
\text { - Presensi sidik jari }\end{array}$ \\
\hline
\end{tabular}




\begin{tabular}{|c|c|c|}
\hline SMA D & $\begin{array}{l}\text { - Klithih } \\
\text { - Sindikat geng se- } \\
\text { kolah 'Ranger' } \\
\text { - Senioritas } \\
\text { - Tawuran dengan } \\
\text { siswa sekolah } \\
\text { lain yang lewat } \\
\text { depan sekolah } \\
\text { dengan mbleyer }\end{array}$ & $\begin{array}{l}\text { - Memasang CCTV di area depan sekolah yang bia- } \\
\text { - } \text { Melakukan pendalaman kasus untuk mencari akar } \\
\text { permasalahan dan solusi } \\
\text { - } \text { Orang tua siswa dan siswa diminta membuat surat } \\
\text { pernyataan bahwa jika hal serupa terulang maka } \\
\text { bersedia untuk dikeluarkan dari sekolah (kesem- } \\
\text { patan diberikan 1x) } \\
\text { - Melakukan wawancara kepada orang tua siswa } \\
\text { dan siswa saat proses penerimaan siswa } \\
\text { - Melakukan analisis siswa dengan potensi penyim- } \\
\text { pangan bawaan dari SMP (siswa yang dari SMP } \\
\text { telah terindikasi melakukan tawuran akan fokus } \\
\text { untuk dibina dan diawasi) } \\
\text { - Orang tua dan siswa diminta menandatangani su- } \\
\text { rat kesanggupan bermaterai terkait kesanggupan } \\
\text { menaati peraturan sekolah } \\
\text { - Sosialisasi peraturan sekolah saat tahun ajaran } \\
\text { baru dan membuat buku kecil yang berisi peratur- } \\
\text { an sekolah kepada siswa dan orang tua } \\
\text { - Membentuk Tim Tata Tertib Sekolah } \\
\text { - Memberlakukan sistem negative point } \\
\text { - Pemanggilan orang tua ke sekolah ketika siswa } \\
\text { mendapat negative point } 30-50 \text { dan melakukan } \\
\text { pembinaan } \\
\text { Menjalin komunikasi melalui pertemuan-pertemuan } \\
\text { dengan orang tua siswa }\end{array}$ \\
\hline SMAE & $\begin{array}{l}\text { - Kasus klith- } \\
\text { ih nongkrong } \\
\text { malam dengan } \\
\text { membawa senja- } \\
\text { ta tajam } \\
\text { - Geng sekolah }\end{array}$ & $\begin{array}{l}\text { - Memanggil orang tua siswa yang bersangkutan ke } \\
\text { sekolah } \\
\text { - } \text { Memfasilitasi gladi rohani dua malam siswa den- } \\
\text { gan orang tua } \\
\text { - } \text { Orang tua-siswa membuat surat perjanjian den- } \\
\text { gan sekolah dan memberikan kesempatan 1x lagi } \\
\text { untuk memperbaiki diri; jika tidak dapat diperbaiki, } \\
\text { maka dikeluarkan dari sekolah } \\
\text { - } \text { Melakukan kerja sama dengan kepolisian untuk } \\
\text { membina siswa dan memberikan materi terkait ba- } \\
\text { haya kekerasan } \\
\text { - Melakukan pelatihan kepemimpinan di Korem } \\
\text { - Menanamkan nilai-nilai cinta kasih } \\
\text { - Melakukan komunikasi dengan orang tua siswa } \\
\text { melalui pertemuan-pertemuan, via telepon, kun- } \\
\text { jungan rumah, mengundang dan membina induk } \\
\text { semang indekos }\end{array}$ \\
\hline
\end{tabular}




\begin{tabular}{|c|c|c|}
\hline SMA F & Kasus tawuran & $\begin{array}{l}\text { - } \text { Pendekatan secara personal } \\
\text { - Murid dengan attitude positif } \\
\text { - Komunikasi dengan orang tua siswa melalui per- } \\
\text { temuan tatap muka, via telepon, grup WA, dan pe- } \\
\text { san singkat perkembangan siswa di balik kertas } \\
\text { ujian siswa. Dulu juga ada komunikasis berbasis } \\
\text { aplikasi, tetapi sekarang tidak lagi karena kendala } \\
\text { orang tua siswa yang kurang familiar dengan ap- } \\
\text { likasi itu } \\
\text { - Memanggil orang tua untuk berdiskusi terkait pen- } \\
\text { anganan siswa yang terlibat klithih termasuk juga } \\
\text { memilihkan sekolah yang lebih cocok dengan sis- } \\
\text { wa yang bersangkutan }\end{array}$ \\
\hline SMA G & $\begin{array}{l}\text { - Klithih } \\
\text { - Tawuran }\end{array}$ & $\begin{array}{l}\text { - Membangun keakraban antara guru dengan siswa } \\
\text { agar guru dapat mengenali karakter siswa, diben- } \\
\text { tuk juga grup WA/LINE antara guru dengan siswa } \\
\text { - } \quad \text { Komunikasi dengan orang tua dilakukan melalui } \\
\text { pertemuan tatap muka, surat, telepon, grup WA, } \\
\text { kunjungan rumah bagi siswa yang membutuhkan } \\
\text { penanganan khusus } \\
\text { - } \text { Pemanggilan orang tua ke sekolah } \\
\text { - } \quad \text { Menjalin kerja sama dengan Polresta untuk mem- } \\
\text { berikan materi terkait bahaya klithih dan geng pe- } \\
\text { lajar kepada siswa dan orang tua siswa } \\
\text { - Membentuk Satgas sekolah yang mengawasi dan } \\
\text { berpatroli di sekeliling sekolah dan memastikan } \\
\text { bahwa setelah jam ekstrakurikuler berakhir, tidak } \\
\text { boleh ada siswa yang nongkrong di sekolah } \\
\text { - Melarang alumni untuk nongkrong di sekolah } \\
\text { - Memberlakukan point negative dan surat peringa- } \\
\text { tan } 1,2 \text {, dan } 3\end{array}$ \\
\hline
\end{tabular}

Sumber: Hasil Analisis, 2017

Banyak penelitian menegaskan pentingnya komunikasi antara orang tua dengan sekolah. Faktor penghambat komunikasi ini umumnya adalah tingkat kesibukan orang tua. Oleh karena itu, komunikasi berbasis teknologi menjadi satu dari sekian alternatif yang efektif untuk digunakan. Aplikasi berbasis teknologi dapat menampung aspirasi orang tua dan juga aspirasi siswa terhadap sekolah dengan lebih leluasa. Komunikasi berbasis teknologi juga sangat membantu sekolah meminimalisasi keterbatasan komunikasi akibat jam belajarmengajar serta keterbatasan komunikasi dengan orang tua yang berada di luar kota atau luar negeri (Clay, 2005: 123).

Hasil penelitian pada Tabel 6 menunjukkan bahwa beberapa SMA telah mencoba menyiasati keterbatasan waktu komunikasi akibat jam belajar-mengajar dengan memanfaatkan teknologi, seperti membuat 
grup WA, LINE, dan komunikasi melalui telepon. Ada beberapa SMA yang juga telah memanfaatkan CCTV untuk memantau aktivitas siswa mereka. CCTV juga digunakan sebagai salah satu cara untuk mengendalikan budaya nongkrong siswa di lingkungan sekitar sekolah, seperti di salah satu SMA negeri di Yogyakarta. Pemanfaatan CCTV ini terbukti mampu menghilangkan kebiasaan nongkrong siswa di SMA tersebut.

Selain penggunaan CCTV, beberapa sekolah juga telah memanfaatkan model presensi berbasis teknologi. Presensi berbasis kartu pernah dilakukan di salah satu SMA yang menjadi sampel penelitian walaupun saat ini telah berganti dengan sistem presensi sidik jari. Presensi sidik jari telah dilakukan di tiga SMA sampel penelitian. Sistem ini dirasa mampu meningkatkan kedisiplinan siswa dan dapat digunakan sebagai bukti untuk melakukan komunikasi dengan orang tua. Komunikasi dengan bukti dirasa sangat penting karena ada beberapa orang tua yang tidak percaya jika anaknya tidak sampai ke sekolah. Hal-hal semacam ini sangat penting untuk meminimalisasi kesalahpahaman antara sekolah dengan orang tua siswa.

Perbedaan penggunaan sistem sidik jari yang dilakukan antara sekolah yang tidak pernah ada kasus kekerasan dengan sekolah yang pernah ada kasus kekerasan terletak pada integrasi sistem presensi sidik jari dengan nomor telepon orang tua. Sekolah yang tidak pernah ada kasus kekerasan justru telah menerapkan sistem presensi sidik jari yang terintegrasi dengan nomor telepon orang tua walapun pemanfaatannya masih perlu dibenahi dalam eberapa hal. Salah satu SMA dengan riwayat tanpa kasus kekerasan juga telah membentuk tim khusus yang menangani sistem informasi berbasis teknologi yang disebut Kominfo. Sistem ini dioperasikan oleh staf khusus yang bertugas mengelola website, media sosial sekolah, serta sistem presensi sidik jari siswa untuk merekap kehadiran siswa, ketidakhadiran siswa, dan keterlambatan siswa. Staf ini juga bertugas menjawab seluruh pertanyaan dan masukan dari pihak orang tua dan siswa terkait dengan kemajuan sekolah. Melalui sistem ini, diharapkan orang tua dapat dengan mudah mengetahui keberadaan anak mereka. Aplikasi akan mengirimkan pesan kepada orang tua apakah anak mereka telah sampai di sekolah, apakah terlambat, atau apakah mereka tidak masuk sekolah. Sistem ini diharapkan untuk memudahkan kontrol orang tua dan sekolah terhadap siswa/anak.

Komunikasi personal antara guru (sekolah) dengan siswa dan orang tua pada era digital saat ini dapat dilakukan menggunakan teknologi informasi, misalnya dengan memanfaatkan media sosial untuk melakukan proses pendidikan. Hal ini akan sangat efektif untuk menghindari kekakuan dalam proses komunikasi di antara mereka.

Dampak positif dari dunia digital dalam hal pendidikan adalah mudahnya akses informasi dengan biaya murah dalam memperoleh informasi pendidikan. Berdasarkan penelitian Digital Citizenship Safety among Children and Adolescents in Indonesia yang dilakukan United Nations International Children's Emergency Fund (UNICEF) pada 2014, ditemukan fakta bahwa dari 30 juta anakanak dan remaja pengguna internet di Indonesia, ada tiga motivasi utama untuk mengakses internet, yaitu mencari informasi, ntuk terhubung dengan teman (lama dan baru), serta hiburan. Pencarian informasi yang dilakukan sering disebabkan oleh tugastugas sekolah, sedangkan penggunaan media sosial dan konten hiburan didorong oleh kebutuhan pribadi. Penelitian terhadap pola komunikasi anak dan remaja melalui internet mengungkapkan bahwa mayoritas 


\section{Tabel 5. Perbedaan Pola Komunikasi Tatap Muka dan Gigital}

\begin{tabular}{lll}
\hline \multicolumn{1}{c}{ Perbedaan } & \multicolumn{1}{c}{ Tatap muka } & \multicolumn{1}{c}{ Digital } \\
\hline Model komunikasi & Formal & Personal \\
Waktu pertemuan & Ditentukan & Setiap saat \\
Biaya & Mahal & Murah \\
$\begin{array}{l}\text { Pemantauan perkembangan } \\
\text { siswa }\end{array}$ & Reguler & Setiap saat \\
\hline
\end{tabular}

Sumber: Hasil Analisis, 2017

komunikasi mereka dilakukan dengan teman sebaya, komunikasi dengan guru, dan komunikasi dengan anggota keluarga yang juga cukup signifikan (http://geotimes. co.id/kolom/kolaborasi-digital-orangtua-dansekolah/).

Fakta tersebut menunjukkan bahwa penggunaan internet oleh anak-anak dan remaja relatif memiliki korelasi dengan pendidikan di rumah maupun sekolah. Ini modal sosial yang harus dioptimalkan untuk membangun kolaborasi digital antara orangtua dan guru dalam mengedukasi anak (Fatimah, 2016). Untuk menciptakan kolaborasi digital antara orantua (keluarga) dan sekolah (guru), ada beberapa strategi yang dijalankan. Diantaranya adalah memanfaatkan teknologi digital untuk mengoptimalkan pola komunikasi, relasi, dan interaksi antara orangtua dan guru. Di era digital, relasi keduanya berpotensi merenggang, jika tidak ditunjang oleh sistem komunikasi, relasi, dan interaksi yang berbasis digital. Membangun sistem berbasis digital sebagai jawaban atas kebutuhan tersebut.

Komunikasi antara orang tua dengan sekolah juga dapat dibina melalui home visit. Kegiatan home visit merupakan satu dari beberapa indikator adanya relasi yang baik antara orang tua dengan sekolah (Hasbullah, 2005: 91-94). Sayangnya, home visit yang dilakukan beberapa sekolah dilakukan ketika siswa sudah melakukan kesalahan/ tindak kekerasan. Beberapa sekolah melakukan home visit ketika siswa sering tidak masuk sekolah, terlibat kasus kekerasan, dll. Terdapat SMA yang tidak memiliki riwayat kasus kekerasan melakukan home visit dengan bentuk pengajian kelas yang dilaksanakan setiap satu bulan sekali. Pengajian ini mampu mendekatkan hubungan antara sekolah dengan orang tua dan sekolah dengan siswa. Selain itu, melalui pengajian ini diharapkan dapat memberikan informasi keagamaan yang dapat membentengi siswa dari hal negatif termasuk terlibat kasus tawuran dan klithih.

Hasil penelitian melalui wawancara mendalam dengan beberapa informan diketahui bahwa pelaku tawuran dan klithih umumnya adalah mereka dengan pengawasan minim dan ada beberapa yang tinggal di indekos. Minimnya pengawasan dan kepedulian dari pemilik dan penjaga indekos akan sangat memengaruhi perilaku anak indekos. Pemberlakuan jam malam akan sangat bermanfaat dalam rangka mencegah kasus klithih yang umumnya terjadi di malam hari. Salah satu SMA mengaku telah mulai melaksanakan pembinaan terhadap induk seman indekos sebagai salah satu wujud pencegahan kasus klithih. Induk semang indekos sebagai pemilik dan pengelola indekos 
juga bertanggung jawab ikut mengawasi anak indekosnya. Kepala Perwakilan UNICEF Indonesia menyebutkan bahwa kekerasan anak adalah krisis yang hanya akan berhenti jika semua pihak dari orang tua, sekolah, pemerintah, dan masyarakat bekerja sama melindungi anak dari bahaya kekerasan, baik sebagai pelaku maupun korban (Lentera Jiwa, 2016: 21).

Informasi keagamaan juga diberikan sebagai salah satu cara menangani kasus klithih. Ketika terjadi kasus klithih yang melibatkan siswanya, SMAtersebut memanggil pelaku dan kedua orang tua mereka untuk sama-sama melakukan gladi rohani. Gladi rohani dilaksanakan selama dua malam sebagai salah satu cara untuk mengembalikan nilai-nilai kebaikan yang ada pada diri siswa. Informasi keagamaan seperti ini hanya diterapkan pada sampel sekolah yang berbasis keagamaan saja. Informasi keagamaan sangat bermanfaat untuk menangani kasus kekerasan siswa karena informasi keagamaan dapat menjadikan siswa memiliki pengendalian diri yang lebih baik (Abror, 2015: 65-66).

Rata-rata sekolah yang menjadi sampel penelitian akan memberikan kesempatan pada siswanya untuk memperbaiki kesalahan dengan memberi satu kali kesempatan lagi. Akan tetapi, jika hal serupa terulang kembali, maka siswa akan dikembalikan ke orang tua masing-masing. Mengeluarkan siswa dari sekolah bukan tidak mungkin justru menambah masalah baru. Pihak sekolah takut siswanya akan terpengaruh oleh siswa yang dikeluarkan karena pertemanan antara anak yang dikeluarkan dengan temennya yang masih bersekolah di sekolah tersebut masih terjalin. Kekhawatiran yang lain adalah terkait penggunaan nama sekolah mereka oleh mantan siswa tersebut jika melakukan tindakan anarkis. Hal seperti ini menunjukkan bahwa mengeluarkan siswa dari sekolah bukan solusi terbaik untuk mengatasi permasalahan tawuran atau klithih. Siswa yang bersangkutan justru akan merasa 'dibuang' dan justru bertindak lebih nekat lagi. Umumnya siswa yang bermasalah dan dikeluarkan dari sekolah akan dipindahkan ke sekolah dengan kualitas yang lebih rendah. Teman-teman yang lebih buruk akan memperparah kondisi siswa yang dikeluarkan tersebut karena lingkungan akan semakin tidak mendukung.

Narapidana kasus kekerasan yang berusia 18 tahun di Lapas Wirogunan (wawancara dilakukan pada 24 Juli 2017, Pukul 10:23 WIB) menuturkan bahwa ia telah tiga kali pindah sekolah. Kepindahannya tersebut karena dikeluarkan dari sekolah sebagai sanksi terlibat tindak kekerasan dan adanya tato di tubuhnya. Setelah dikeluarkan dari sekolah lama dan pindah ke sekolah baru, siswa tersebut masih bergabung di geng sekolah lama, bergaul dengan teman yang sama, dan tetap memakai identitas sekolah lama ketika melaksanakan tindak kekerasan. Kondisi ini memperlihatkan bahwa menempatkan siswa sebagai pihak yang bersalah dan memojokkannya tidak akan menyelesaikan permasalahan. Budaya memojokkan siswa hanya akan semakin membuat siswa menjauhi guru, tidak memiliki kepercayaan kepada guru, dan akan mengulang hal yang sama (Chairani, 2009: 148).

Hasil wawancara dengan salah satu kepala sekolah menyebutkan bahwa dulu ada siswa sekolah tersebut yang terlibat kasus tawuran. Penanganan yang dilakukan pihak sekolah adalah tidak mengeluarkan siswa yang bersangkutan. Sekolah juga tidak meminta siswa tersebut menandatangani surat perjanjian apa pun. Sekolah lebih menekankan pada pendekatan personal serta merangkul siswa dan orang tua siswa untuk sama-sama memperbaiki diri. Hal yang telah terjadi sebaiknya tidak perlu diungkit kembali 
dan sebaiknya dijadikan pembelajaran. Cara sekolah menangani kasus tersebut terbukti mampu mengurangi, bahkan menghilangkan kasus serupa sampai saat ini.

Keinginan untuk dimengerti menjadikan siswa SMA terkadang berperilaku negatif sebagai wujud protes terhadap lingkungan sekitarnya. Sekolah dan orang tua sebagai pihak yang bertanggung jawab atas perkembangan siswa harus mampu memahami siswa, termasuk ketika siswa berbuat kesalahan (dalam hal ini terlibat kasus tawuran dan klithih). Memberikan poin negatif ketika bersalah tanpa memberikan poin positif ketika berprestasi seakan menunjukkan ketidakadilan bagi siswa. Siswa akan merasa dipersalahkan atas semua hal yang telah terjadi tanpa diberi kesempatan untuk memperbaiki semuanya. Salah satu sampel SMA memberikan poin positif kepada siswanya yang berprestasi, baik prestasi akademik maupun nonakademik. SMA tersebut, bahkan akan memberikan pengurangan poin negatif dari perolehan poin positif tersebut.

Masa SMA merupakan masa ketika mereka membutuhkan pengakuan dari lingkungan sekitar dan masa penuh dengan kreativitas serta energi. Kreativitas dan energi ini akan menjadi sesuatu yang siasia jika tidak diberikan wadah. Sekolah harus berupaya memfasilitasinya dengan menyediakan berbagai ekstrakulikuler. Siswa dapat memilih berbagai jenis ekstrakulikuler sesuai dengan minat mereka. Salah satu sampel SMA menerapkan kewajiban kepada siswanya untuk mengikuti minimal satu jenis ekstrakurikuler.

Siswa SMA saat ini menghadapi berbagai tantangan seiring dengan perkembangan zaman dan teknologi. Berbagai ancaman dan manfaat kemajuan tersebut dapat datang secara bersamaan, bergantung kepada daya tahan dari setiap individu (siswa) yang bersangkutan. Untuk dapat bertahan dalam kemajuan zaman yang sekarang, setiap individu (siswa) harus dibekali dengan penguatan karakter. Berdasarkan hasil penelitian, diketahui beberapa sekolah telah menerapkan upaya pendidikan karakter melalui kerja sama dengan Kodim dan Korem. Kegiatan ini diharapkan dapat menumbuhkan semangat nasionalisme, kedisiplinan, dan memperkuat karakter mereka. Akan tetapi, hasil penelitian belum menemukan informasi bahwa pendidikan karakter telah dimasukkan ke dalam kurikulum sebagai mata pelajaran tersendiri.

Upaya pencegahan kasus kekerasan dan klithih di kalangan siswa SMA juga dapat dilakukan dengan membangun komunikasi dan kerja sama antara sekolah dengan masyarakat. Jika dilihat, rata-rata kejadian tawuran siswa terjadi di luar kegiatan belajarmengajar dan di luar lingkungan sekolah. Hal ini menunjukkan bahwa kepedulian masyarakat terhadap potensi kejadian tawuran sangat penting (http://megapolitan.kompas. $\mathrm{com} / \mathrm{read} / 2017 / 07 / 17 / 13560241 /$ cegahtawuran-polres-jaksel-bubarkan-pelajar-yangnongkrong-di-pinggir). Masyarakat yang berdomisili di daerah rawan (daerah yang biasa digunakan untuk kegiatan nongkrong) dapat melaporkan aktivitas-aktivitas anarkis kepada pihak kepolisian. Lebih lanjut pihak kepolisian dapat menangani hal tersebut dan mencegah hal-hal yang tidak diinginkan. Oleh karena itu, upaya pencegahan dan penanganan kasus kekerasan dan klithih harus melibatkan semua pihak, baik itu dari orang tua, sekolah, aparat kepolisian, dan juga masyarakat (Pangestuti, dkk., 2016: 21).

\section{Kesimpulan}

Dari hasil penelitian yang diuraikan sebelumnya, maka dapat disimpulkan beberapa hal berikut. 
1. Maraknya aksi tawuran pelajar yang terjadi di Yogyakarta bukanlah sebuah fenomena yang baru.

2. Penyebab utama tindakan tawuran pelajar adalah lemahnya peran keluarga, terutama orang tua dalam pengasuhan anak sehingga menjadikan anak salah dalam bergaul.

3. Peran sekolah, terutama guru BK ataupun wali kelas, diharapkan mampu menerapkan komunikasi efektif dalam mengajarkan, mendorong, mengubah sikap dan keyakinan, serta mengubah perilaku negatif siswa.

4. Terjalinnya relasi yang baik antara orang tua dan sekolah penting dilakukan dalam rangka mengetahui perkembangan si anak didik, terutama dalam penanganan kekerasan pelajar.

5. Pada era digital sekarang ini, pola komunikasi yang paling efektif adalah dengan memanfaatkan teknologi informasi digital dalam membangun relasi antara siswa, orang tua, serta sekolah dalam melihat dan memantau pendidikan anak.

\section{Daftar Pustaka}

Abror, Ahmad. 2015. Peran Guru Agama Islam dalam Pencegahan Kenakalan Remaja Tahun 2015. Semarang: UIN Walisongo Semarang.

Adisty, L. O. 2012. "Peran Masyarakat diperlukan untuk Mencegah Tawuran". http://megapolitan.kompas.com/ read/2012/09/25/04393919/Peran. Masyarakat.Diperlukan.untuk.Mencegah. Tawuran. Diakses pada Selasa, 1 Agustus 2017, Pukul 08.15 WIB.

Ainin, Luthfiah Nur. 2014. "Hubungan Pola Asuh Orang Tua dengan Kenakalan Remaja di RW V Kelurahan Sidokare Kecamatan Sidoarjo".
Jurnal Keperawatan dan Kebidanan Stikes Dian Husada Mojokerto 6(1).

Ali, Hasanuddin, dkk. 2016. INDONESIA 2020: The Urban Middle-Class Millennials. Jakarta: Alfara Research Center.

Baedowi, Ahmad, dkk. 2015. Manajemen Sekolah Efektif. Jakarta: PT. Pustaka Alfabet.

Vahedi, Majid. 2010. "A Study of Parent's Participation in The High School Administration and its Effect on School Activities". Procedia Social and Behavioural Sciences 2: 359-363.

Basri, Hasan.1996. Remaja Berkualitas:

Problematika Remaja dan Solusinya. Yogyakarta: Pustaka Pelajar.

Clay, Susan, Graham. 2005. "Communicating with Parents: Strategies for Teachers". The School Community Journal, 117-130.

Dilogi. 2017. "Bergesernya Makna Klithih ke Arah yang Negatif", http://dilogi.student. uny.ac.id/2017/03/31/184/, diakses pada Selasa, 11 Juli 2017, Pukul 10.30 WIB.

Fatimah. 2016. "Kolaborasi Digital Orangtua dan Sekolah". https://geotimes.co.id/ kolaborasi-digital-orangtua-dan-sekolah/, diakses pada Sabtu, 15 Juli 2017, Pukul 22.20 WIB.

Hasan Basri.1996. Remaja Berkualitas: Problematika Remaja dan Solusinya. Yogyakarta: Pustaka Pelajar.

Hasbullah. 2005. Dasar-Dasar Ilmu Pendidikan. Jakarta: PT. Raja Grafindo Persada.

Hernawan, Arif Koes. 2017. "Kapolda Minta Istilah "Klithih" Dihilangkan". https:// www.gatra.com/nusantara/jawa/250500kapolda-minta-istilah-klithih-dihilangkan. diakses pada Selasa, 11 Juli 2017, Pukul 14.00 WIB.

Iwe. 2012. "Perang antar Geng Pelajar". http:// jogja.tribunnews.com/2012/01/06/ini-datatawuran-di-kota-yogya. Diakses pada Selasa, 11 Juli 2017, Pukul 11.00 WIB. 
Jatmika, Sidik. 2010. Genk Remaja: Anak haram Sejarah ataukah Korban Globalisasi? Yogyakarta: Kanisius.

Kurniawan, Bagus. 2016. “Kapolda DIY: Sepanjang 2016, 43 Kasus Kriminal Didominasi Pelajar". (http://news.detik. com/berita/d-3382743/kapolda-diysepanjang-2016-43-kasus-kriminaldidominasi-pelajar) diakses pada $11 \mathrm{Juli}$ 2017, pukul 13.00 WIB.

Lidyasari, Aprilia Tina. t.t. "Pola Asuh Otoratif sebagai Sarana Pembentukan Karakter Anak dalam Setting Keluarga". http:// staffnew.uny.ac.id/upload/132309077/ penelitian/ARTIKEL+POLA+ASUH.pdf. diakses pada 4 Agustus 2017.

Makmun, Syamsudin Abin. 1999. Psikologi Pendidikan. Bandung: Remaja Rosdakarya. Mulyana, D. 2002. Komunikasi Suatu Pengantar. Bandung: Remaja Rosdakarya. Mustika, K. 2009. "Komunikasi interpersonal guru dan orang tua dalam mencegah kenakalan remaja pada siswa SMA Kolombo Sleman". Jurnal IImu Komunikasi 7(2):143-152.

Nailufar, Nibras Nada. 2017. "Cegah Tawuran, Polres Jaksel Bubarkan Pelajar yang Nongkrong di Pinggir Jalan". http:// megapolitan.kompas.com/read/2017 /07/17/13560241/cegah-tawuran-polresjaksel-bubarkan-pelajar-yang-nongkrongdi-pinggir. diakses pada 11 Juli 2017, pukul 15.00 WIB.

Raharjo, Edzan. 2016. "Kasus Tawuran Pelajar di Yogyakarta Meningkat di Tahun 2016". https://news.detik.com/berita/d-3383483/ kasus-tawuran-pelajar-di-yogyakartameningkat-di-tahun-2016. diakses pada 11 Juli 2017, pukul 14.30 WIB.

Rohmawati. 2015. Pelaksanaan Sistem Seleksi Penerimaan Siswa Baru di MA Pembangunan UIN Jakarta. Jakarta: UIN Syarif Hidayatullah Jakarta.
S. Hasan, B. 2015. "Fenomena tawuran antar pelajar dan intervensinya". Jurnal Hisbah 12(1):1-25.

Sarwirini. 2011. "Kenakalan Anak (Juvenile Deliquency): Kausalitas dan Upaya Penanggulangannya". http://ejournal.uwks. ac.id/myfiles/201209442514478516/5.pdf. Jurnal. PERSPEKTIF XVI(4) Tahun 2011 Edisi September. Diakses pada Minggu, 16 Juli 2017, Pukul 17.24 WIB.

Syarif, H. 2013. "Pengaruh Kerjasama Orang Tua dan Guru Terhadap Disiplin Peserta Didik". Jurnal IImiah Widya 1(1): 92-99.

Sujatmoko, Andrey. 2016. "Hak atas Pemulihan Korban Pelanggaran Berat HAM: di Indonesia dan Kaitannya dengan Prinsip Tanggung Jawab Negara dalam Hukum Internasional". Jurnal IImu Hukum 2(2). Univ. Padjadjaran.

Unayah, Nunung, dkk. 2015. "Fenomena Kenakalan Remaja dan Kriminalitas". https:// media.neliti.com/media/publications/52810ID-fenomena-kenakalan-remaja-dankriminalit.pdf, diakses pada Selasa, 11 Juli 2017, Pukul 11.45 WIB.

Warih, A. 2012. "Tawuran pelajar dalam perspektif kriminologis, hukum pidana, dan pendidikan". Jurnal IImiah Widya 324:34-40.

Wicandra, Obed Bima. 2016. "Graffiti di Indonesia: Sebuah Politik Identitas Ataukah Tren? Kajian Politik Identitas pada Bomber di Surabaya". Jurnal Desain Komunikasi Visual Nirmana 8(2).

Yog, dkk. 2014. "Cah Klithih: Ancaman Hukuman Lebih Lima Tahun Penjara". https://www.radarjogja.co.id/cah-klithihancaman-hukuman-lebih-lima-tahunpenjara/. Diakses pada Selasa, 11 Juli 2017, Pukul 09.40 WIB.

Pangestuti, Ratna Dewi, dkk. 2016. "Membangun Benteng Hadapi Kekerasan Pada Anak". Media Komunikasi RSJSLentara Jiwa. Edisi 35: 20-21. 